\title{
Correction to: Plasmodium - a brief introduction to the parasites causing human malaria and their basic biology
}

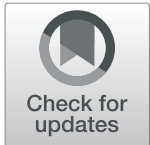

Shigeharu Sato ${ }^{1,2}$

\author{
Correction to: J Physiol Anthropol 40, 1 (2021) \\ https://doi.org/10.1186/s40101-020-00251-9
}

It was highlighted that the original article [1] contained an incorrect sentence in the fourth paragraph of the section Recurrence of malaria and the hypnozoite. This Correction article shows the incorrect and correct sentence. The original article has been updated.

\section{Incorrect sentence}

A P. malariae case caused by blood transfusion from a donor who had probably acquired the infection over 40 years ago has also been reported.

\section{Correct sentence}

A P. malariae case that most likely developed after an asymptomatic infection lasted over 40 years has also been reported.

Published online: 29 January 2021

\footnotetext{
Reference

1. Sato. Plasmodium - a brief introduction to the parasites causing human malaria and their basic biology. J Physiol Anthropol. 2021;40:1 https://doi. org/10.1186/s40101-020-00251-9.
}

\footnotetext{
The original article can be found online at https://doi.org/10.1186/s40101020-00251-9.

Correspondence: ukssato@gmail.com

${ }^{1}$ Borneo Medical and Health Research Centre, Faculty of Medicine and Health Sciences, Universiti Malaysia Sabah, Jalan UMS, 88400 Kota Kinabalu, Sabah, Malaysia

${ }^{2}$ Department of Pathobiology and Medical Diagnostics, Faculty of Medicine and Health Sciences, Universiti Malaysia Sabah, Jalan UMS, 88400 Kota

Kinabalu, Sabah, Malaysia
}

(C) The Author(s). 2021 Open Access This article is licensed under a Creative Commons Attribution 4.0 International License, which permits use, sharing, adaptation, distribution and reproduction in any medium or format, as long as you give appropriate credit to the original author(s) and the source, provide a link to the Creative Commons licence, and indicate if changes were made. The images or other third party material in this article are included in the article's Creative Commons licence, unless indicated otherwise in a credit line to the material. If material is not included in the article's Creative Commons licence and your intended use is not permitted by statutory regulation or exceeds the permitted use, you will need to obtain permission directly from the copyright holder. To view a copy of this licence, visit http://creativecommons.org/licenses/by/4.0/. The Creative Commons Public Domain Dedication waiver (http://creativecommons.org/publicdomain/zero/1.0/) applies to the data made available in this article, unless otherwise stated in a credit line to the data. 